\title{
Ligneous conjunctivitis
}

\author{
J. C. MaGRAND, D. M. REES, AND J. HARRY
}

From the Royal Eye Hospital, London, the Sutton General Hospital, Surrey, and the Department of Pathology, Institute of Ophthalmology, University of London

Ligneous conjunctivitis is a rare form of conjunctival disease which derives its name from the fact that the eyelids are classically described as feeling woody on palpation. The essential feature of the condition, however, is the presence of an irregular elevated mass of hyalinized connective tissue which arises from the affected conjunctiva.

One of the earliest references to what would seem to have been this condition was by von Graefe (1854) and altogether about fifty cases have now been described in the literature. Borel (1933) gave the condition its distinctive name, but since then several other descriptive terms have been used. Verhoeff (1958) coined the term "recurrent postmembranous granuloma of the palpebral conjunctiva" which, although long, summarizes the clinical features of a pseudo-membranous or membranous conjunctivitis followed by the development of an indurated plaque which usually recurs rapidly despite repeated abscissions.

Ligneous conjunctivitis tends to occur in young children, mainly females, and may affect other members of the same family. It is often bilateral and corneal involvement leading to loss of the eye may be a complication. The aetiology is unknown. Howe ( 1897 ) gave a pathological description of a conjunctival membrane and suggested a bacteriological approach to diagnosis. Many agents have been suggested as being responsible for the lesion, but although an infective process would seem likely, as in many other varieties of conjunctivitis, no satisfactory proof of this has so far been produced. Several different types of bacteria have, in fact, been isolated from affected eyes, but sterilization of the conjunctiva has neither cured nor prevented further membrane formation and the organisms have been considered to be incidental to the disease. The association in some of the reported cases of systemic signs, such as nasopharyngitis and vaginitis, has suggested a virus aetiology, but this again is unconfirmed. Attempts to isolate rickettsiae and fungi have also been unsuccessful. In the treatment of the condition many varieties of both medical and surgical methods have been used, ranging from the simple instillation of antibiotic drops to excision of all the involved parts followed by a grafting procedure. The results of therapy, however, tend to be disappointing.

\section{Case reports}

Case r, 5-week-old baby boy, was seen at the Royal Eye Hospital, London in July, 1965. His left eye had been swollen and discharging for about 3 weeks, the condition having developed during the postnatal period in the maternity unit.

\section{Examination}

The right eye was normal with no discharge. The left eye showed a moderate degree of swelling of the upper and lower lids and a heavy mucopurulent exudate appeared to be adherent to the tarsal 
conjunctiva. The cornea and intraocular tissues were not involved and there was no regiona lymphadenopathy. The general condition of the child was satisfactory.

Progress

After admission to hospital and vigorous treatment with irrigations, topical antibiotics, and systemie sulphonamides, the discharge rapidly lessened and by the next day it was noted that a large cheese mass of what appeared to be granulation tissue was protruding downwards from the upper lid tक cover most of the cornea. A similar but smaller mass was seen to be arising from the tarsal con $\widehat{D}$ junctiva of the lower lid. These were considered to be either true or pseudo-membranes. Tho lower lesion gradually became smaller and disappeared, but the upper one persisted unaltered.? There was also a mild sticky discharge from the eye.

After a month, the mass from the upper lid was removed under general anaesthesia. The con $\overrightarrow{\vec{\omega}}$ dition, however, returned to its former state within 3 days, and 2 months later a second excision was performed and the base of the denuded area was painted with silver nitrate. At these two operations 0 . the excision involved removal of the tissue from the whole inner surface of the upper lid and fornix There was a little bleeding from the cut surface and the removed specimens were soft and fleshy.

Following the second operative procedure, a mass returned within 3 days, but clinically thi appeared dry and encrusted. During the following months this mass gradually became smaller an $\sigma^{\omega}$ it had disappeared completely by the time the child was 9 months old. Throughout the whole of this period local treatment with various antibiotic preparations and simple lotions was maintained $\vec{c}$ This made no obvious difference to the appearance of the membrane, but the discharge from the ey was less noticeable. The child was last seen when $2 \mathrm{I}$ months old and both eyes and adnexae were then quite normal.

\section{Histological examination}

The material removed from the lid on the second occasion was submitted for histological examination (Figs I-3). Sections showed a mass consisting of irregular, non-birefringent, eosinophilic, hyalinizech deposits associated with granulation tissue. Both acute and chronic inflammatory cells were seen⿳亠口冋 and in some areas eosinophils were conspicuous. There was, in addition, a little haemorrhage Islands and strands of partly degenerate epithelium were incorporated within the mass which was also partly covered at the periphery by epithelium. The eosinophilic areas stained bright red with Picro-Mallory stain, thus demonstrating the fibrinous nature of the deposit, but otherwise differentiat staining revealed neither amyloid nor mucin. No bacteria or fungi were demonstrable.

conjunctival cultures Pneumococci and coagulase-positive Staphylococcus aureus were cul윽 tured on several occasions, but these were sparse growths and unrelated to any obvious change ir the condition of the membrane. No fungi were isolated on either blood-agar or Sabouraud's medium.

CONJUNCTIVAL SMEARS No inclusion bodies of the TRIC type were found.

BLOOD EXAmination Haemoglobin: i $18 \mathrm{~g}$. $/$ IOo ml. $=80$ per cent. Total white cell count 7, $100 / \mathrm{cu} . \mathrm{mm}$. differential normal. Erythrocyte sedimentation rate: $7 \mathrm{~mm}$. in I hour.

Case 2, a young woman aged 18 years, first attended Sutton General Hospital, Surrey, iñ February, 1967, complaining of a swelling under the right upper eyelid. This had been present for a few weeks, but had caused little discomfort apart from a slight sensation of heaviness in the lid. .9 There were no other symptoms. It was stated by the patient's mother that a membrane had been present beneath the right upper lid when she was 2 weeks old. This had recurred after beingo removed in hospital on three occasions and did not disappear completely until the patient was Io months old. Between this time and the present attendance, there had been no further ocular芭 complaints. 

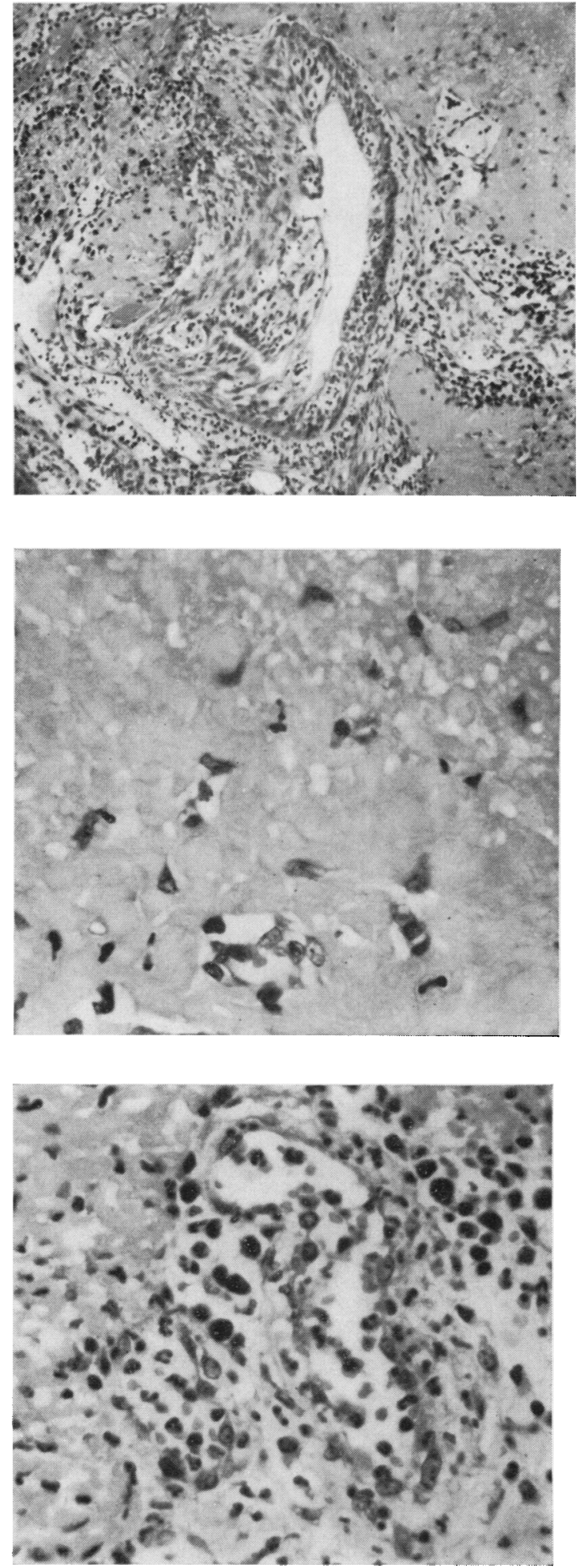

FIG. I Islands of epithelial cells incorporated within a mass of inflamed granulation tissue and eosinophilic, hyalinized deposit. Haematoxylin and eosin $\times 85$

FIG. 2 Eosinophilic, hyalinized deposit. Haematoxylin and eosin $\times 420$

FIG. 3 Inflamed granulation tissue. Haematoxylin and eosin $\times 420$ 


\section{Examination}

Visual acuity in each eye was $6 / 6$ unaided. The left eye was normal in all respects. Eversion o $\overline{\bar{B}}$ the right upper lid revealed an elevated hard mass with an indurated base arising from the tarsal. conjunctiva (Fig. 4). There was no ptosis, the lower lid was normal, and no other ocular abnor $\overrightarrow{\overrightarrow{\vec{b}}}$ mality was detected. There was no regional lymphadenopathy and general physical examinatioro revealed no abnormality.

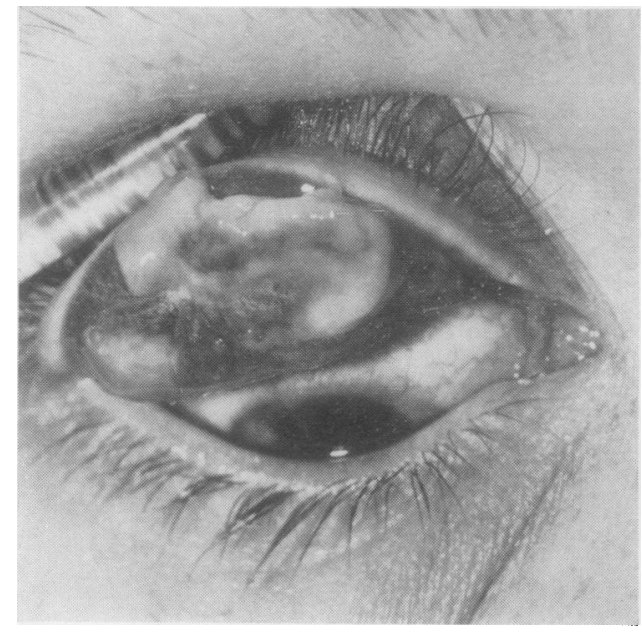

FIG. 4 Elevated hard mass arising from tarsal ơ conjunctiva of right upper lid

\section{Progress}

A week after the patient's first visit to hospital, the mass was excised flush with the adjacent conjunc tival surface and the bed was noted to be granular and bleeding. Within a week, however, the mass 0 had regrown to its original size. The patient continued to be observed and 3 months later a furtherö excision of the mass was performed. After this procedure there was no rapid recurrence, but a mucoid exudate was seen to be forming at the operation site. In an attempt to clear this exudate, 20 per cent. acetylcysteine drops (a mucolytic agent) were instilled into the affected eye six times a day. The treatment was begun on the ninth postoperative day, but in spite of this the mass graduallyo. reformed and grew to its original size within 3 weeks. There has since been no obvious change ando the patient is continuing to be observed.

\section{Histological examination}

Sections of the first mass to be excised showed granulation tissue together with an eosinophilic, hyalinized deposit. No epithelium was seen and no micro-organisms were demonstrable.

The second mass to be excised was submitted to a more extensive histopathological study (Figs $5-7$, opposite).

Sections again showed granulation tissue in which large numbers of blood vessels were present. $\tilde{D}$ Both acute and chronic inflammatory cells were seen, there was some haemorrhage, and inflamed degenerate epithelium was present. Irregular deposits of non-birefringent eosinophilic, hyalinized material as seen in Case I were a conspicuous feature and Picro-Mallory stain again showed these tơ be of a fibrinous nature. As in Case 1 , other differential stains for amyloid and mucin were negative and bacteria and fungi were not demonstrable.

\section{Electron microscopy}

Electron-microscopical studies were carried out on a small portion of the material removed on the $\mathbb{D}$ second occasion. It was seen that beaded filaments were laterally aligned to form banded 

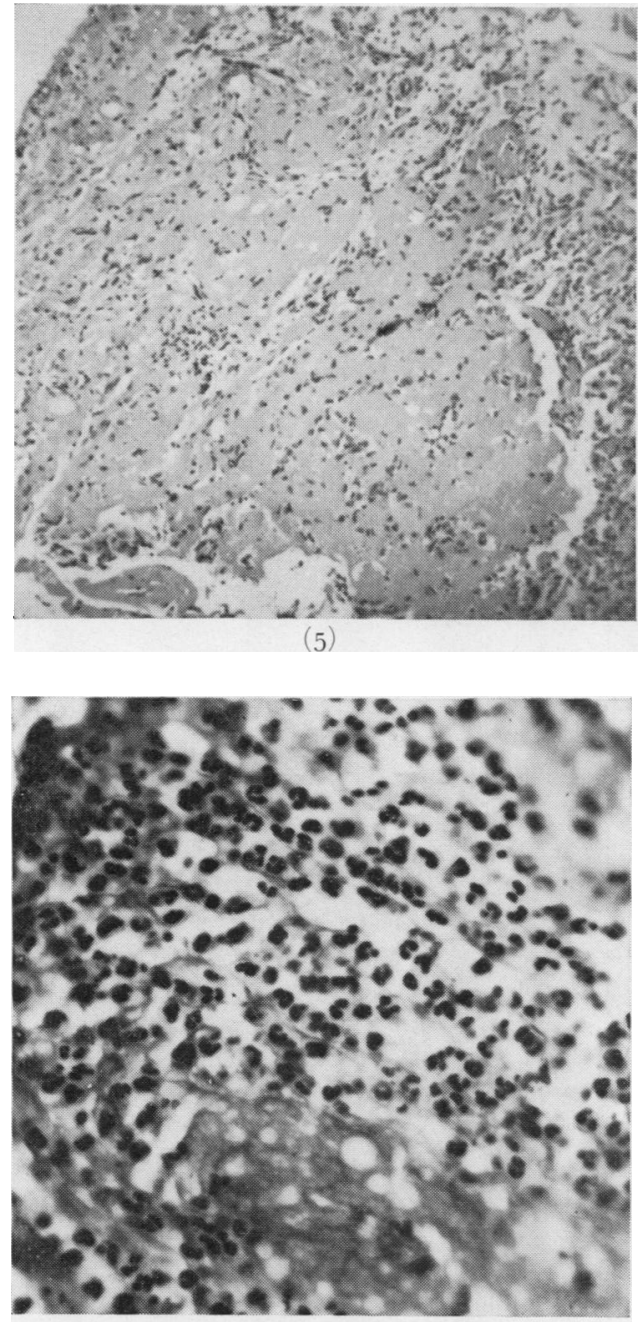

(7)

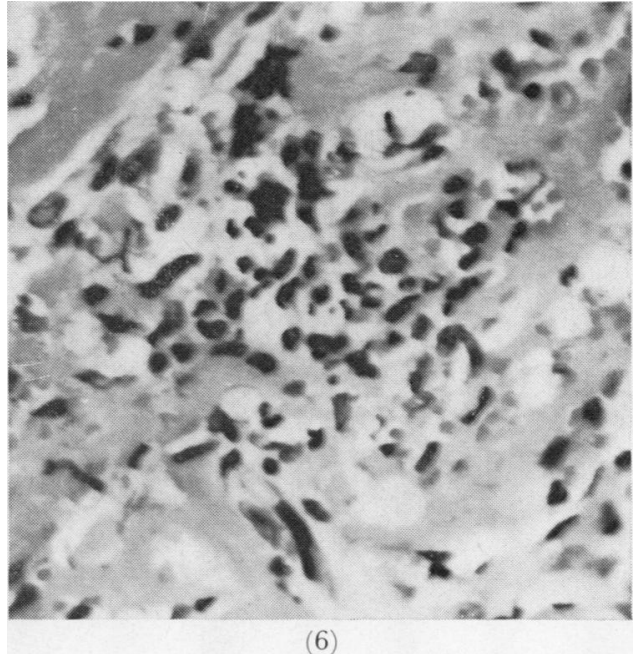

FIG. 5 Large irregular areas of eosinophilic, hyalinized tissue with associated inflammation. Haematoxylin and eosin $\times 85$

FI G. 6 Acute and chronic inflammatory cell infiltrate. Haematoxylin and eosin $\times 420$

FIG. 7 Inflamed degenerate epithelium. Haematoxylin and eosin $\times 420$

fibrils having a periodicity of $200 \AA$. The fibrinous nature of the deposit was thus confirmed (Fig. 8, overleaf). There was no evidence to suggest the presence of a virus.

CONJÜnTIVAL GULTURES No bacteria or fungi were grown on blood-agar.

GONJUNCTIVAL SMEARS No TRIC inclusion bodies were seen.

BLOOD examination Haemoglobin: $12.5 \mathrm{~g} . / 100 \mathrm{ml}$. $=84$ per cent. Total white cell count: 5,80o/cu. mm. Erythrocyte sedimentation rate: $8 \mathrm{~mm}$. in $\mathrm{I}$ hour. Total protein: $7.6 \mathrm{~g} . / 100 \mathrm{ml}$. Electrophoretic strip of serum proteins showed a slight increase in $a_{2}$ globulins. Alkaline phosphatase: 6 units/10o $\mathrm{ml}$. Zinc turbidity: 2 units/100 $\mathrm{ml}$. Direct bilirubin: negative. Total bilirubin: $0.5 \mathrm{mg}$./100 $\mathrm{ml}$. Lupus erythematosus cells not present.

Immunological studies

IMMUNOFLUORESGENGE TESTS Sections $5 \mu$ thick were cut from the excised mass, fixed in cold alcohol, and treated by the direct and indirect immunofluorescent technique using antihuman immunoglobulin fluorescein conjugate. Fluorescence of hyaline bodies was observed, but this 


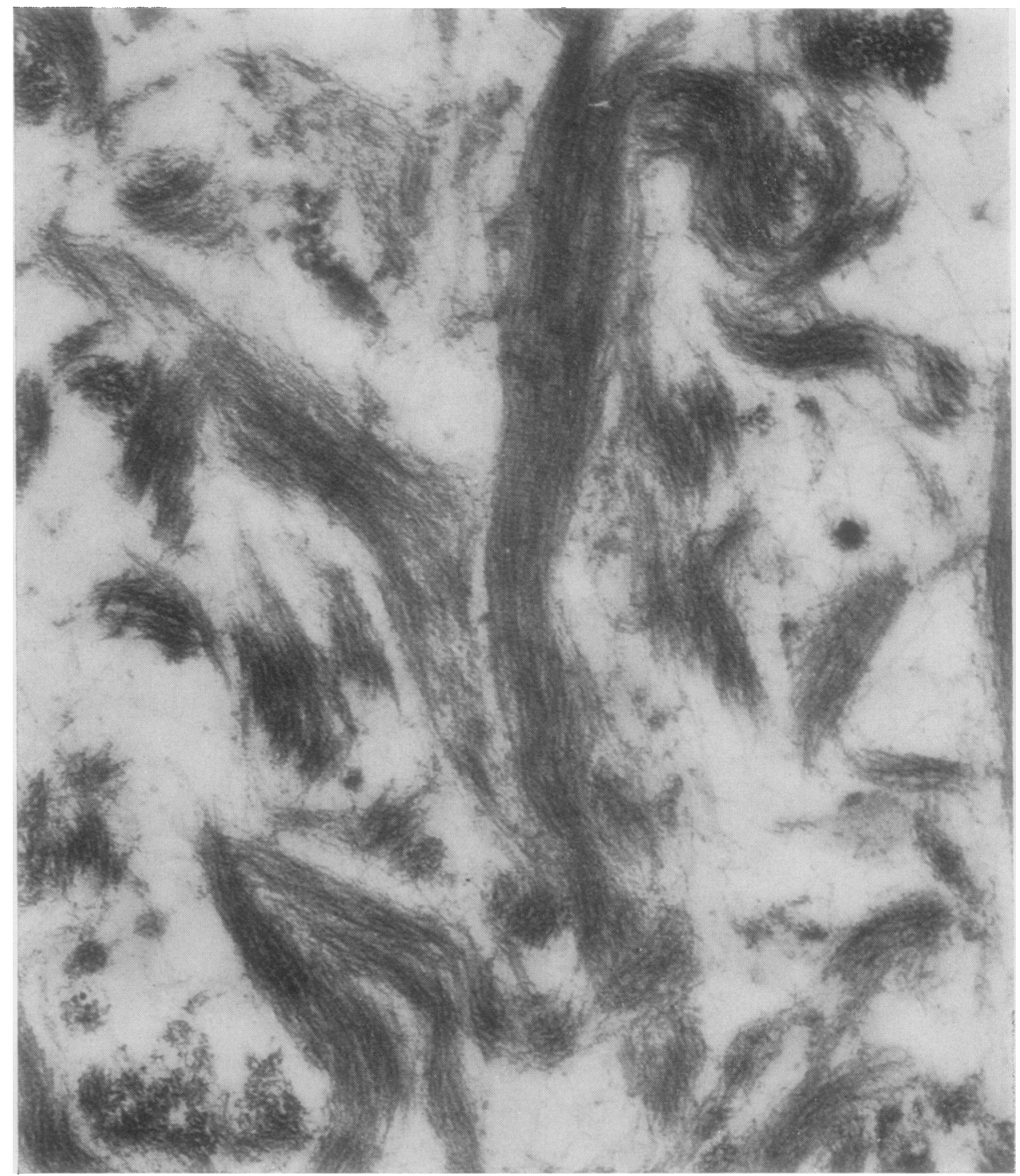

FIG. 8 Electron micrograph illustrating fine fibrillar nature of deposit. Fibrils show banding at periodicity $200 \AA$. Zetterqvist buffered osmium tetroxide fixed-araldite/epon embedded. $\quad \times 45,000$

proved to be an autofluorescence since the intensity of fluorescence was the same as that seen of examination of an untreated section. Blocking tests failed to eliminate or decrease the intensity $\mathscr{E}_{0}$ fluorescence. Thus immunoglobulin binding could not be demonstrated in the specimen.

IMMUNOGLOBULIN SERUM ESTIMATIONS These were as follows, the corresponding normat figures as estimated by the same laboratory being in brackets:

$$
\begin{array}{lr}
\text { Immunoglobulin } G=650 \mathrm{mg} \text {. per cent. } & (\mathrm{I}, 286) \\
\text { Immunoglobulin } \mathrm{A} & =190 \mathrm{mg} \text {. per cent. } \\
\text { Immunoglobulin } \mathrm{M}=\mathrm{I} \text { 7 } 75) & \mathrm{mg} \text {. per cent. }
\end{array}
$$

These figures are not suggestive of an autoimmune mechanism. 
Virus studies

Tissue cultures A throat swab and also a part of the excised tissue from the lid were examined for the presence of virus by the inoculation of primary monkey kidney, primary human amnion, and HeLa cell tissue cultures, and by the inoculation of the yolk sac of 7 -day-old fertile hens' eggs. All the results were negative.

SERUM ANTIBODIES

Complement-fixation tests

\begin{tabular}{|c|c|c|c|}
\hline Antigen & Titre & Antigen & Titre \\
\hline $\begin{array}{l}\text { Influenza A } \\
\text { Influenza B } \\
\text { Influenza C } \\
\text { Sendoi } \\
\text { Parainfluenza } 3 \\
\text { Psittacosis-LVG }\end{array}$ & $<\mathrm{I} / \mathrm{IO}$ & $\begin{array}{l}\text { C. burnettii } \\
\text { Respiratory syncytial virus } \\
\text { Measles } \\
\text { Eaton's agent } \\
\text { Adenovirus } \\
\text { Mumps "S", } \\
\text { Mumps "V" }\end{array}$ & $<\mathrm{I} /$ io \\
\hline
\end{tabular}

There was thus no evidence of infection with any of these viruses.

\section{Discussion}

Conjunctivitis with membrane formation can result from many different causes. Hogan (1947) classified chronic ligneous conjunctivitis as a membranous conjunctivitis due to unknown or uncertain causes, but suggested that some of the reported cases were due to micro-organisms. He believed that most of them were of streptococcal origin, and considered that future cases would be classified among the other recognized groups of bacterial conjunctivitis. Verhoeff (1958), in describing a chronic case of ligneous conjunctivitis and reviewing the literature relating to the condition, stated that there was usually an associated nasopharyngitis, and considered that the primary infectious agent was probably a filterable virus.

Apart from the apparent absence of upper respiratory involvement, the two cases described in this paper are fairly typical, from both the clinical and pathological viewpoints, of ligneous conjunctivitis. Thus Case I was a persistent membranous conjunctivitis appearing in an infant, and Case 2 had a childhood history of what was probably a membranous conjunctivitis, but presented again in adult life with a hard and elevated lid lesion. Neither of the patients, however, had corneal lesions, the presence of which are mentioned by Paufique and Moreau (1953) as a cardinal sign of the disease. The absence of systemic features and the involvement of only one eyelid may account for this, for in the more severe variety of the condition with a tendency to perforation of the globe, involvement of all four eyelids and extra-ocular manifestations are more common. In this respect it is of interest to note that the case described by Verhoeff ( $195^{8}$ ) had conjunctival lesions for over 30 years without impairment of vision, and no mention is made of any systemic symptoms. It seems likely that, as suggested by François (I966), there are two varieties of the condition, one with and one without associated systemic disturbances.

Despite the fairly extensive investigations undertaken, particularly in Case 2, no further light has been shed on the question of the aetiology of the condition. The bacteria cultured from the conjunctival sac in Case I are considered to be incidental to the disease, and there is thus no convincing evidence of a causative agent in either case.

The possibility that an autoimmune mechanism might be involved in the disease was considered. Neither case, however, showed a raised ESR, and in Case 2 attempts to 
demonstrate circulating immunoglobulins and cell-bound antibodies failed to revea? evidence of autoimmunity.

Many of the cases of ligneous conjunctivitis previously described (Goldmann and Ho I 954; Paufique and Moreau, I 953; Winter and Michler, I 953) show a familial and hered tary tendency. In addition, Winter and Michler (1953) were able to produce a membrano by trauma in their cases and this evidence tended to suggest that membrane formatio might have been due not only to hereditary susceptibility but to some abnormal tissug response to injury. Factors likely to have resulted in this response, however, were noథ suggested. François ( 1966 ) demonstrated mucopolysaccharide material in tissue from biopsy of ligneous conjunctivitis, and in view of this he felt that a disturbance in the metabolism of the conjunctiva, perhaps with a hereditary basis, was the main factor in the $\vec{E}$ aetiology of the condition.

The histopathological findings in the cases under discussion appear to differ little from those previously described. There is a fibrinous deposit associated with a degree $\mathcal{\leftrightarrow H}_{0}$ inflammatory cell infiltration and the later development of a hyalinized mass of connectiv\& tissue, these changes being secondary to increased permeability of the conjunctival blooछ vessels with an outpouring of serofibrinous transudate which subsequently undergoes coagulation with the resultant formation of granulation and connective tissue. The factors responsible for this increased vascular permeability, however, are at preserf unknown, but an autoimmune mechanism should not be excluded on the basis of negative findings in Case 2, and further investigations along these lines are indicated iff future cases.

As regards treatment of the condition, the position is still very unsatisfactory. Aparo from surgical removal of the membranous mass, other treatments which have given soms measure of success include irrigations with streptodornase, streptokinase, and hyaluroni dase. Spaeth (1967) recently reported a case which showed limited improvement afte范 combined treatment with idoxuridine and cytosine arabinoside and the simultaneous administration of systemic and topical corticosteroids. The application of $\beta$ rays and $x$ rays after excision of the mass has been tried but with only a limited degree of success Héry, Demailly, and Dhermy (I966) recommend an extensive procedure of completé removal of the lesion from the affected lid to leave only skin, and the application of $\frac{0}{\sigma}$. buccal graft to the bare area, followed by $x$-irradiation. It is felt, however, that such a operation is not indicated if the patient remains relatively free from symptoms.

In Case $\mathrm{I}$ the mass resolved spontaneously after a period of about 9 months although the regular use of antibiotics may have expedited its cure and prevented keratitis. It is interesting to speculate whether a recurrence will be seen at a later date. In Case 2 th situation remains unaltered. A postoperative course of mucolytic eye drops was given i⿱丷三. an attempt to prevent recurrence after the second abscission, but without success. In vieng of the lack of symptoms it is not proposed to perform any further surgery at present.

In conclusion, the question of nomenclature of this condition should be considered. pointed out by Verhoeff (1958), the term "chronic membranous conjunctivitis" is inaccug rate, for in the stage when the disease is inflammatory and membranous it is not chronic but acute, and when it becomes chronic it is not inflammatory. In the absence of any specifie histopathological change and with the aetiology uncertain, in order to distinguish this disorder from chronic conjunctivitis with membrane formation in which the aetiology known, the only alternative name we would suggest is "idiopathic recurrent membranou conjunctivitis". In the present state of our knowledge, however, there seems little advar $\mathbb{B}$ tage in changing the accepted but rather unsuitable term of ligneous conjunctivitis. 


\section{Summary}

The general features of ligneous conjunctivitis are mentioned. Two cases of the condition are described. Investigations as to aetiology are considered, and particular reference is made to the possibility of a virus infection or an autoimmune process. Other possible causative factors are mentioned. The unsatisfactory state of present methods of treatment are noted, and it is considered that in the absence of severe symptoms radical surgical treatment is not indicated. The question of terminology is discussed.

We are grateful to Miss M. Savory and Miss D. A. Birks for permission to publish details of their cases. We are indebted to Dr. T. Lehner of the Department of Dental Medicine and Pathology, Guy's Hospital, London, for the immunological studies and to Dr. R. Gamble of the Public Health Laboratory, Epsom, for the virological studies. Our thanks are due to the Department of Medical Illustration, Institute of Ophthalmology, for the clinical photograph, to Mr. B. Llewellyn for technical assistance and for the preparation of the photomicrographs, to Mr. D. Wood and Mr. P. Denney for the electron micrograph, and to Miss A. Martyn for secretarial assistance. Finally we should like to thank Prof. Norman Ashton for his valuable criticism of the paper.

\section{References}

BOREL, G. (1933) Bull. Soc. franç. Ophtal., 46, I68

FRANÇOIs, J. (1966) In discussion on Héry and others (1966), p. 284

goldmann, H., and hof, w. (1954) Schweiz. med. Wschr., 84, 73

Graefe, A. von (1854) v. Graefes Arch. Ophthal., 1, abt. I, p. 168

HÉRY, J., DEMAILly, P., and DHERMY, P. (1966) Bull. Soc. Ophtal. Fr., 66, 277

hogan, м. J. (1947) Amer. 7. Ophthal., 30, I 495

howe, L. (I897) Trans. Amer. ophthal. Soc., 8, 36

PAUfiQue, L., and moreau, P. G. (I953) Ann. Oculist. (Paris), 186, 12

SPAETH, G. L. (1967) Amer. 7. Ophthal., 64, 300

VERHOEFF, F. H. (1958) Ibid., 45, No. 4, pt 2, p. 246

wiNTER, F. C., and Michler, R. R. (1953) A.M.A. Arch. Ophthal., 49, I6 I 